\title{
Chryseobacterium vrystaatense sp. nov., isolated from raw chicken in a chicken-processing plant
}

\author{
Correspondence \\ Hanli de Beer \\ hdebeer@cut.ac.za
}

\author{
Hanli de Beer, ${ }^{1}$ Celia J. Hugo, ${ }^{2}$ Piet J. Jooste, ${ }^{3}$ Anne Willems, ${ }^{4}$ \\ Marc Vancanneyt, ${ }^{5}$ Tom Coenye ${ }^{4}$ and Peter A. R. Vandamme ${ }^{4}$ \\ ${ }^{1}$ School for Agriculture and Environmental Science, Central University of Technology: \\ Free State, P/bag ×20539, 1 Pres. Brandt Street, Bloemfontein 9300, South Africa \\ ${ }^{2}$ Department of Microbial, Biochemical and Food Biotechnology, University of the Free State, \\ Bloemfontein, South Africa \\ ${ }^{3}$ Department of Biotechnology and Food Technology, Tshwane University of Technology, \\ Pretoria, South Africa \\ 4,5Laboratorium of Microbiology ${ }^{4}$ and BCCM/LMG Bacteria Collection ${ }^{5}$, Ghent University, \\ K.L. Ledeganckstraat 35, Ghent B-9000, Belgium
}

Yellow-pigmented, Gram-negative organisms isolated from raw chicken were investigated by means of a polyphasic taxonomic approach and were shown to represent a novel species in the genus Chryseobacterium, for which the name Chryseobacterium vrystaatense sp. nov. is proposed. Its nearest phylogenetic neighbours were Chryseobacterium joostei, Chryseobacterium indologenes and Chryseobacterium gleum, which showed 16S rRNA gene sequence similarity levels of $96 \cdot 9,97 \cdot 1$ and $96 \cdot 1 \%$, respectively. Levels of DNA-DNA hybridization between strains of $C$. vrystaatense and Chryseobacterium reference species were below $46 \%$. Strain LMG $22846^{\top}$ (=CCUG $50970^{\top}$ ) was chosen as the type strain and has a DNA G $+\mathrm{C}$ content of $37 \cdot 1 \mathrm{~mol} \%$.
Flavobacteria and pseudomonads are traditionally known to cause spoilage in food and food products (Forsythe, 2000, pp. 96-98 and 101-103). In the literature on meat spoilage, 'flavobacteria' is used as a generic name for yellowpigmented rods (Hendrie et al., 1969). Usually, pathogens such as Salmonella and Campylobacter are associated with poultry, but large numbers of other bacteria often associated with spoilage are found on poultry carcasses. These include many so-called flavobacteria that may originate from the poultry itself or from the abattoir environment and which are responsible for spoilage (Hang'ombe et al., 1999). Mai \& Conner (2001) found that the incidence of members of the genus Pseudomonas and flavobacteria on chicken carcasses was 17 and $16 \%$, respectively. The incidence of flavobacteria

Published online ahead of print on 3 June 2005 as DOI 10.1099/ ijs.0.63746-0.

The GenBank/EMBL/DDBJ accession numbers for the 16S rRNA gene sequences of Chryseobacterium vrystaatense LMG $22846^{\top}$ and LMG 22954 are AJ871397 and AJ871398, respectively.

A dendrogram derived from the unweighted pair group mean linkage of correlation coefficients between the whole-cell protein profiles of $C$. vrystaatense and reference strains of related taxa and a table detailing the strains investigated and their origin are available as supplementary material in IJSEM Online. on poultry is much higher than on other fresh meat (Nychas \& Drosinos, 1999).

Over the past decade, many changes have taken place in the taxonomy of the family Flavobacteriaceae, and the revised genus Flavobacterium comprises mainly aquatic bacteria that are not known in food microbiology (Bernardet et al., 1996). Several former Flavobacterium species were transferred to the novel genus Chryseobacterium (Vandamme et al., 1994) and novel species have been described, including Chryseobacterium joostei (Hugo et al., 2003), Chryseobacterium defluvii (Kämpfer et al., 2003), Chryseobacterium miricola (Li et al., 2003) and, most recently, Chryseobacterium formosense (Young et al., 2005), Chryseobacterium daecheongense (Kim et al., 2005a) and Chryseobacterium taichungense (Shen et al., 2005). 'Chryseobacterium proteolyticum' was described by Yamaguchi \& Yokoe (2000), but its name has not been validly published. In addition, two Chryseobacterium species, Chryseobacterium meningosepticum and Chryseobacterium miricola, have been reclassified into the novel genus Elizabethkingia (Kim et al., 2005b). In general, these Chryseobacterium species are widely distributed in water, soil and the clinical environment, but they are also found in food specimens, such as milk, meat, poultry and fish (Jooste \& Hugo, 1999). 
During a study investigating the incidence of yellowpigmented strains isolated from meat, 36 yellow-pigmented isolates were obtained from raw chicken, at different stages of processing, from a local chicken-processing plant in the Vrystaat province (Free State, South Africa). Informtion regarding the investigated isolates, their origin and number is given in the Supplementary Table (available in IJSEM Online). The spoilage ability of this group of strains has not yet been determined. Chryseobacterium reference strains were available from the BCCM/LMG Bacteria Collection. After growth for $24 \mathrm{~h}$ on trypticase soy agar (BBL), cells were harvested and whole-cell protein extracts were prepared and subjected to whole-cell protein electrophoresis as described by Pot et al. (1994). A densitometric analysis, normalization and interpolation of the protein profiles, and a numerical analysis were performed by using the GelCompar software package (Applied Maths). The 36 isolates formed three subgroups comprising 19, four and 13 isolates, respectively. Isolates belonging to the three subgroups differed mainly in the density of some protein bands (see Supplementary Figure in IJSEM Online).

High-molecular-mass DNA was prepared according to the methods of Pitcher et al. (1989) from a representative isolate of each of these three subgroups, i.e. isolates LMG $22846^{\mathrm{T}}$, LMG 22848 and LMG 22847, and from Chryseobacterium reference strains (see below). DNA-DNA hybridizations were performed with photobiotin-labelled probes in microplate wells as described by Ezaki et al. (1989), using an HTS7000 Bio Assay Reader (Perkin Elmer) for the fluorescence measurements. The hybridization temperature was $33^{\circ} \mathrm{C}$. Hybridization values obtained among the three isolates were $>92 \%$, demonstrating that the three subgroups formed a homogeneous genospecies.

In order to determine the phylogenetic position of this taxon, the 16S rRNA gene sequences of strains LMG $22846^{\mathrm{T}}$ and LMG 22954 were determined as described by Willems et al. (2003). The 16S rRNA gene sequences of strains LMG $22846^{\mathrm{T}}$ and LMG 22954 showed $99 \cdot 9 \%$ similarity to each other and $96 \cdot 9,97 \cdot 1$ and $97 \cdot 1 \%$ similarity to those of C. joostei, Chryseobacterium indologenes and Chryseobacterium gleum, respectively, demonstrating that the taxon represented by these two strains belonged to the genus Chryseobacterium. Values towards the other type strains investigated were $<96 \%$. Fig. 1 illustrates the phylogenetic position of this taxon within the genus Chryseobacterium. Subsequent DNA-DNA hybridizations between the type strains of the latter three species yielded a value of $46 \%$ between strain LMG $22846^{\mathrm{T}}$ and C. joostei LMG $18212^{\mathrm{T}}$; the other values were between 27 and $32 \%$.

In order to determine its $\mathrm{G}+\mathrm{C}$ content, DNA was degraded enzymically into nucleosides as described by Mesbah et al. (1989). The nucleoside mixture obtained was then separated by HPLC using a Waters SymmetryShield C8 column regulated at $37^{\circ} \mathrm{C}$. The solvent was $0.02 \mathrm{M} \mathrm{NH}_{4} \mathrm{H}_{2} \mathrm{PO}_{4}$, $\mathrm{pH} 4 \cdot 0$, with $1 \cdot 5 \%$ acetonitrile. Non-methylated lambda phage DNA (Sigma) was used as the calibration reference. The detector used was a Waters model 484 UV-VIS absorbance detector set at $270 \mathrm{~nm}$. The DNA G $+C$ contents of strains LMG $22846^{\mathrm{T}}$, LMG 22847 and LMG 22848 were $37 \cdot 1,37 \cdot 0$ and $37 \cdot 6 \mathrm{~mol} \%$, respectively, within the range of 34-38 mol\% reported for the genus Chyseobacterium (Vandamme et al., 1994).

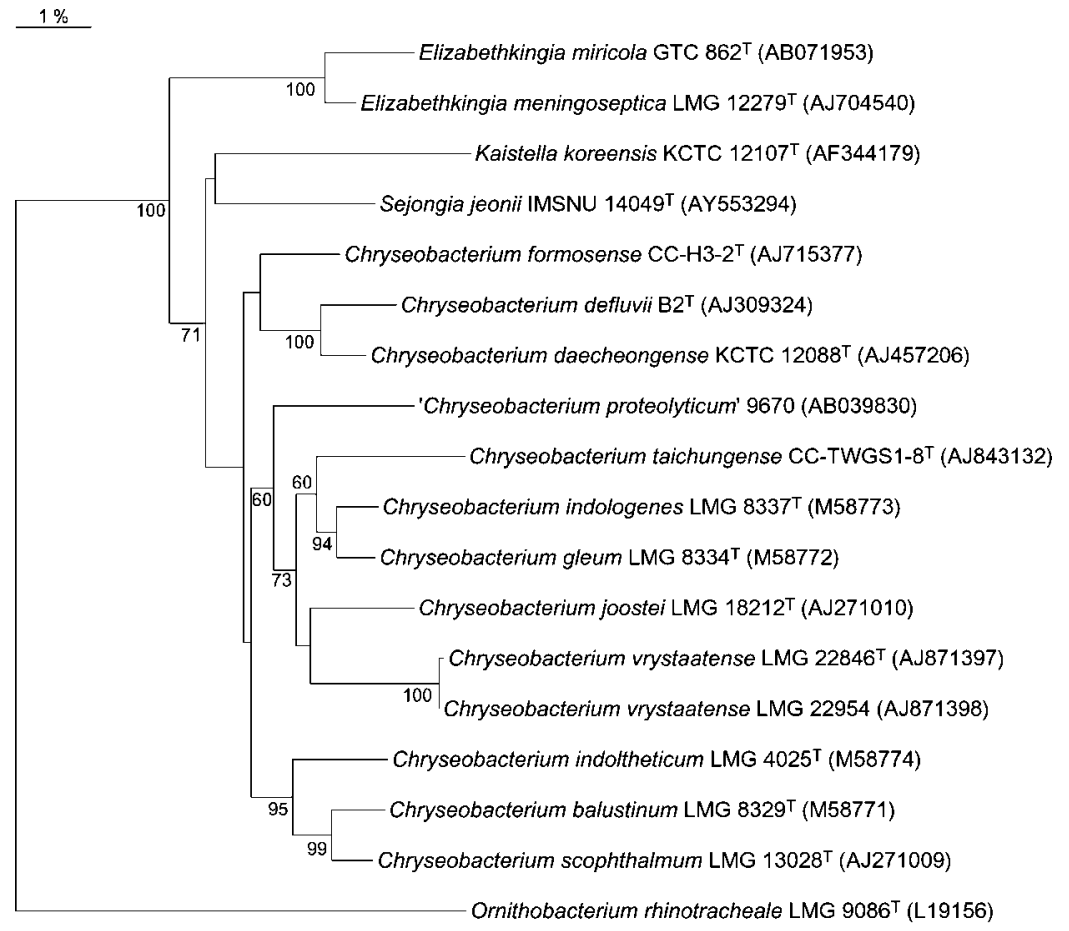

Fig. 1. Neighbour-joining phylogenetic tree of Chryseobacetrium vrystaatense sp. nov. and related bacteria based on 16S rRNA gene sequence comparisons. Bootstrap values above $60 \%$ obtained from 1000 repetitions are indicated. The 16S rRNA gene sequence of Ornithobacterium rhinotracheale LMG $9086^{\top}$ was included as outgroup. 
Table 1. Long-chain fatty acid composition of Chryseobacterium species and related taxa

Taxa: 1, C. vrystaatense sp. nov. $(n=7) ; 2$, C. indoltheticum $(n=1) ; 3$, C. balustinum $(n=1) ; 4$, C. gleum $(n=5) ; 5$, C. indologenes $(n=45)$; 6, C. scophthalmum $(n=2) ; 7$, C. joostei $(n=11) ; 8$, C. defluvii $(n=1)$; 9, C. formosense $(n=1)$; 10, C. daecheongense ( $n=1)$; 11, C. taichungense $(n=1) ; 12$, Elizabethkingia meningoseptica $(n=1) ; 13$, Elizabethkingia miricola $(n=1)$. Fatty acid percentages amounting to $<1 \cdot 0 \%$ of the total fatty acids in all strains were not included. tr, Trace (for values $<1 \%$ ); NA, not available; ND, not detected; ECL, equivalent chain length (i.e. the identity of the fatty acids is unknown). Means $\pm \mathrm{SD}$ are given for C. vrystaatense only. Data are taken from Hugo et al. (2003) (2-7, 12), Li et al. (2003) (13), Young et al. (2005) (9), Kim et al. (2005a) (10) and Shen et al. (2005) (11).

\begin{tabular}{|c|c|c|c|c|c|c|c|c|c|c|c|c|c|}
\hline Fatty acid & 1 & 2 & 3 & 4 & 5 & 6 & 7 & 8 & 9 & 10 & 11 & 12 & 13 \\
\hline ECL $13 \cdot 566$ & $1 \cdot 4 \pm 0 \cdot 3$ & $1 \cdot 7$ & $1 \cdot 6$ & $1 \cdot 2$ & $2 \cdot 1$ & $2 \cdot 9$ & $1 \cdot 1$ & $\operatorname{tr}$ & $\operatorname{tr}$ & $1 \cdot 5$ & $6 \cdot 7$ & $1 \cdot 5$ & $\operatorname{tr}$ \\
\hline Iso- $\mathrm{C}_{15: 0}$ & $41 \cdot 8 \pm 1 \cdot 4$ & $29 \cdot 4$ & $32 \cdot 3$ & $35 \cdot 4$ & $34 \cdot 3$ & $35 \cdot 0$ & $34 \cdot 6$ & $58 \cdot 5$ & $52 \cdot 2$ & $51 \cdot 2$ & $35 \cdot 4$ & $41 \cdot 4$ & $33 \cdot 0$ \\
\hline Iso- $\mathrm{C}_{15: 0} 3-\mathrm{OH}$ & $2 \cdot 7 \pm 0 \cdot 3$ & $2 \cdot 3$ & $2 \cdot 7$ & $2 \cdot 5$ & $2 \cdot 6$ & $2 \cdot 7$ & $2 \cdot 9$ & $2 \cdot 6$ & $1 \cdot 8$ & $2 \cdot 0$ & $4 \cdot 3$ & $3 \cdot 5$ & $3 \cdot 0$ \\
\hline Iso- $\mathrm{C}_{16: 0} 3-\mathrm{OH}$ & $\operatorname{tr}$ & $1 \cdot 3$ & $\operatorname{tr}$ & ND & $\mathrm{ND}$ & $\mathrm{ND}$ & $\mathrm{ND}$ & $\operatorname{tr}$ & $1 \cdot 1$ & $\operatorname{tr}$ & $1 \cdot 4$ & $\operatorname{tr}$ & $8 \cdot 0$ \\
\hline ECL $16 \cdot 580$ & $1 \cdot 2 \pm 0 \cdot 2$ & $1 \cdot 3$ & $1 \cdot 3$ & $1 \cdot 7$ & $1 \cdot 7$ & $1 \cdot 5$ & $1 \cdot 6$ & $\operatorname{tr}$ & $1 \cdot 0$ & $1 \cdot 0$ & $1 \cdot 7$ & $1 \cdot 7$ & $\operatorname{tr}$ \\
\hline Iso- $\mathrm{C}_{17: 0}$ & $\operatorname{tr}$ & $\operatorname{tr}$ & $1 \cdot 0$ & $1 \cdot 6$ & $\operatorname{tr}$ & $\operatorname{tr}$ & $\operatorname{tr}$ & $2 \cdot 0$ & $2 \cdot 3$ & $3 \cdot 0$ & $\operatorname{tr}$ & $\operatorname{tr}$ & $1 \cdot 0$ \\
\hline Iso- $\mathrm{C}_{17: 0} 3-\mathrm{OH}$ & $15 \cdot 4 \pm 1 \cdot 8$ & $14 \cdot 0$ & $16 \cdot 8$ & $21 \cdot 8$ & $19 \cdot 2$ & $16 \cdot 3$ & $20 \cdot 1$ & $14 \cdot 1$ & $10 \cdot 9$ & $15 \cdot 7$ & $22 \cdot 4$ & $16 \cdot 3$ & $40 \cdot 0$ \\
\hline Iso- $\mathrm{C}_{17: 1} \omega 9 c$ & $19 \cdot 7 \pm 2 \cdot 3$ & $25 \cdot 6$ & $27 \cdot 1$ & $20 \cdot 2$ & $24 \cdot 2$ & $24 \cdot 8$ & $22 \cdot 9$ & $4 \cdot 8$ & $4 \cdot 3$ & $7 \cdot 6$ & $8 \cdot 9$ & $7 \cdot 0$ & $\operatorname{tr}$ \\
\hline
\end{tabular}

${ }^{\star}$ Summed feature 3 comprises $\mathrm{C}_{16: 1} \omega 7 c$ and/or iso- $\mathrm{C}_{15: 0} 2-\mathrm{OH}$; summed feature 4 comprises iso- $\mathrm{C}_{15: 0} 2-\mathrm{OH}$ and $\mathrm{C}_{16: 1} \omega 7 c t$; summed feature 5 comprises iso- $\mathrm{C}_{17: 1} \mathrm{I}$ and/or anteiso- $\mathrm{C}_{17: 1} \mathrm{~B}$.

The whole-cell fatty acid components of seven strains representing the three subgroups and of Chryseobacterium reference strains were prepared from a loopful of wellgrown cells incubated for $24 \mathrm{~h}$ at $28^{\circ} \mathrm{C}$. Separation and identification of esters were performed with the Sherlock Microbial Identification system (MIDI version 3.0) as described by Vandamme et al. (1992). Mean percentages and SD were calculated and are shown in Table 1. As for other Chryseobacterium species, the predominant fatty acids were iso- $\mathrm{C}_{15: 0}(40-43 \%)$, iso- $\mathrm{C}_{17: 1} \omega 9 c(16-21 \%)$ and iso$\mathrm{C}_{17: 0} 3-\mathrm{OH}(15-18 \%)$.

A detailed phenotypic characterization of the 36 isolates and of Chryseobacterium reference species was subsequently performed. A $24 \mathrm{~h}$ culture, incubated at $25^{\circ} \mathrm{C}$, was suspended in a quarter-strength Ringer solution to give a McFarland Barium Sulphate Standard 2 suspension. A battery of tests was selected to differentiate species in the genus at $25^{\circ} \mathrm{C}$ according to the methods described by Cowan (1974), MacFaddin (1980), Gerhardt et al. (1981) and Hugo et al. (2003). Twenty-two isolates were subjected to Biolog GN2 MicroPlate (Biolog Inc.) tests according to the manufacturer's protocol. Test results are given below in the species description and in Table 2, which includes the biochemical tests useful for the differentiation of the novel species from recognized Chryseobacterium species.
The results of the present study demonstrate that the collection of 36 yellow-pigmented isolates from raw chicken represent a novel species in the genus Chryseobacterium, for which we propose the name Chryseobacterium vrystaatense sp. nov.

\section{Description of Chryseobacterium vrystaatense sp. nov.}

Chryseobacterium vrystaatense (vry.staa.ten'se. N.L. neut. adj. vrystaatense named after Vrystaat (Free State), the South African province where these bacteria were isolated).

Colonies are shiny, orange-yellow and translucent with entire edges. Cells are Gram-negative, catalase- and oxidasepositive and produce flexirubin-type pigments; they are non-motile and neither oxidative nor fermentative. Colonies are seen after $24 \mathrm{~h}$ growth at $4,15,25$ and $32^{\circ} \mathrm{C}$ on nutrient agar, but no growth occurs at $37^{\circ} \mathrm{C}$ or above. Growth on MacConkey agar no. 3 (Oxoid CM115) is observed after $48 \mathrm{~h}$ at 15,25 and $32{ }^{\circ} \mathrm{C}$ for all but one strain that grows only on MacConkey agar after $48 \mathrm{~h}$ at $32{ }^{\circ} \mathrm{C}$. All strains grow in nutrient broth containing 1 and $2 \% \mathrm{NaCl}$ $(\mathrm{w} / \mathrm{v})$; growth in $3 \% \mathrm{NaCl}$ broth is strain-dependent $(14$ strains, excluding the type strain, test positive for growth). Although several strains initially show growth at different salt concentrations, only five show growth in $4 \% \mathrm{NaCl}$ 
Table 2. Phenotypic properties that differentiate C. vrystaatense sp. nov. from other Chryseobacterium species and related taxa

Taxa: $1, C$. vrystaatense $(n=36) ; 2, C$. indoltheticum $(n=1) ; 3, C$. balustinum $(n=1) ; 4$, C. gleum $(n=1) ; 5, C$. indologenes $(n=1)$; 6, C. scophthalmum $(n=1) ; 7$, C. joostei $(n=1) ; 8$, C. defluvii $(n=1) ; 9$, C. formosense $(n=1) ; 10, C$. daecheongense $(n=1) ; 11$, C. taichungense $(n=1) ; 12$, Elizabethkingia meningoseptica $(n=1)$; 13, Elizabethkingia miricola $(n=1)$. Data are taken from $\mathrm{Li}$ et al. (2003) (13), Young et al. (2005) (9), Kim et al. (2005a) (10) and Shen et al. (2005) (11). +, Positive; W, weakly positive; -, negative; D, delayed; NA, not available.

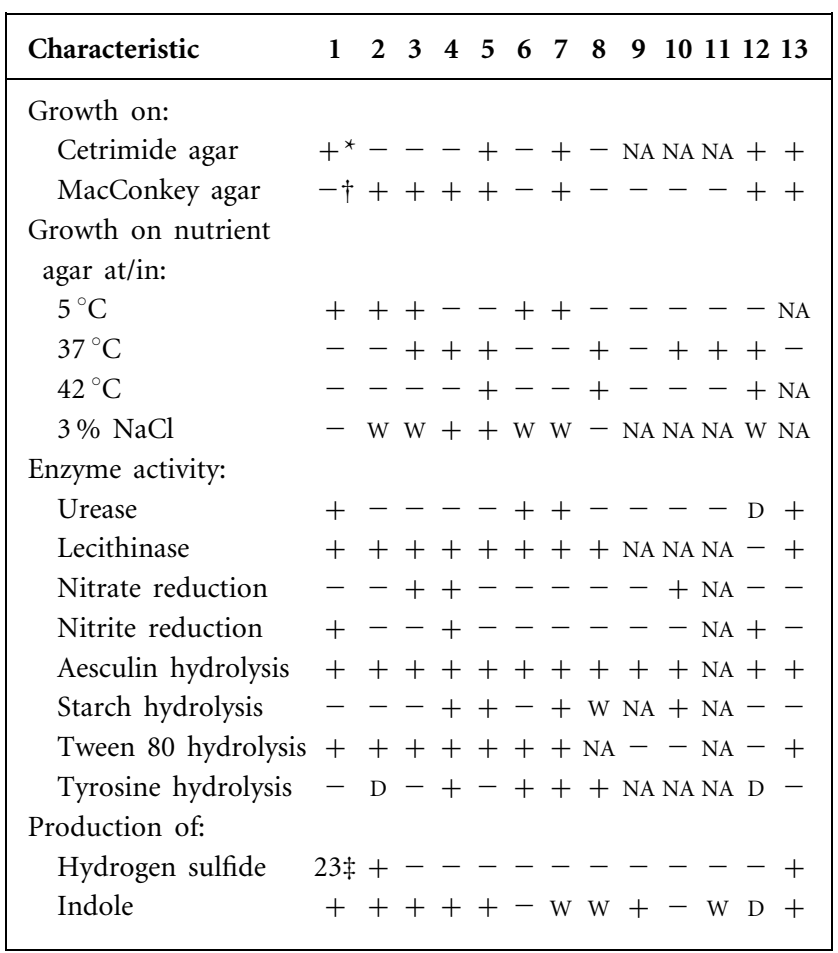

Variable reactions are scored as: ${ }^{*}$ positive for all strains except R23519, R-23533 and R-23598; †the majority of strains were negative, although some grew after $48 \mathrm{~h}$ at $25^{\circ} \mathrm{C}$.

$\$$ Number of strains that tested positive, including the type strain.

broth after 5 days incubation (R-23493, R-23569, R-23575, R-23576 and R-23595). Strains show strong DNase activity and also urease and lecithinase activity, but no starch or tyrosine hydrolysis. Reactions on triple-sugar agar (Oxoid CM277) and $10 \%$ lactose are alkaline. Ability to produce $\mathrm{H}_{2} \mathrm{~S}$ varies depending on incubation time on triple-sugar agar and SIM medium (Oxoid CM435). Both media contain sodium thiosulfate, but SIM medium also contains ferrous ammonium sulfate and $>50 \%$ of strains give a positive reaction. All strains tested $(n=22)$ show positive reactions in the Biolog system for Tweens 40 and 80 , gentobiose, $\alpha$-Dglucose, D-mannose, D-trehalose, succinic acid monomethyl ester, acetic acid and L-asparagine. At least 19 of the strains $(85 \%)$ react for glycyl L-glutamic acid, glycerol, L-glutamic acid, L-serine and L-aspartic acid. Reactions in which more than $50 \%$ of the strains give a positive result are for dextrin $(n=16)$, D-mannitol $(n=18), \alpha$-ketovaleric acid $(n=15)$, L-alanylglycine $(n=12)$, L-threonine $(n=16)$, inosine $(n=13)$, uridine $(n=15)$ and thymidine $(n=12)$.

The type strain, LMG $22846^{\mathrm{T}}$ ( $=$ CCUG $50970^{\mathrm{T}}$ ), was isolated from a raw chicken-portion sample obtained from a chicken-processing plant. The other (35) isolates were obtained from raw-chicken samples, collected at different processing stages (portion, whole bird, automatic line, manual line and the spiral freezing process) on different occasions. Three additional isolates have been deposited in the BCCM/LMG Bacteria Collection as LMG 22847, LMG 22848 and LMG 22954.

\section{Acknowledgements}

This project was funded by the National Research Foundation, South Africa. We are indebted to the Fund for Scientific Research - Flanders (Belgium) for positions as postdoctoral fellows (T.C. and A.W.) and research grants (P.A. R. V.).

\section{References}

Bernardet, J.-F., Segers, P., Vancanneyt, M., Berthe, F., Kersters, K. \& Vandamme, P. (1996). Cutting a Gordian knot: emended classification and description of the genus Flavobacterium, emended description of the family Flavobacteriaceae, and proposal of Flavobacterium hydatis nom. nov. (basonym, Cytophaga aquatilis Strohl and Tait 1978). Int J Syst Bacteriol 46, 128-148.

Cowan, S. T. (1974). Cowan and Steel's Manual for the Identification of Medical Bacteria, 2nd edn. Cambridge: Cambridge University Press.

Ezaki, T., Hashimoto, Y. \& Yabuuchi, E. (1989). Fluorometric deoxyribonucleic acid-deoxyribonucleic acid hybridization in microdilution wells as an alternative to membrane filter hybridization in which radioisotopes are used to determine genetic relatedness among bacterial strains. Int J Syst Bacteriol 39, 224-229.

Forsythe, S. J. (2000). The Microbiology of Safe Food. London: Blackwell Science.

Gerhardt, P., Murray, R. G. E., Costilow, R. N., Nester, E. W., Wood, W. A., Krieg, N. R. \& Phillips, G. B. (1981). Manual of Methods for General Bacteriology. Washington, DC: American Society for Microbiology.

Hang'ombe, B. M., Sharma, N. R., Skjerve, E. \& Tuchili, L. M. (1999). Isolation of bacteria during processing of chicken carcasses for the market in Lusaka, Zambia. Veterinarski Arhiv 69, 191-197.

Hendrie, M. S., Mitchell, T. G. \& Shewan, J. M. (1969). The identification of yellow pigmented rods. In Identification Methods for Microbiologists, part B, pp. 67-78. Edited by B. M. Gibbs \& D. A. Shapton. London: Academic Press.

Hugo, C. J., Segers, P., Hoste, B., Vancanneyt, M. \& Kersters, K. (2003). Chryseobacterium joostei sp. nov., isolated from the dairy environment. Int J Syst Evol Microbiol 53, 771-777.

Jooste, P. J. \& Hugo, C. J. (1999). The taxonomy, ecology and cultivation of bacterial genera belonging to the family Flavobacteriaceae. Int J Food Microbiol 53, 81-94.

Kämpfer, P., Dreyer, U., Neef, A., Dott, W. \& Busse, H.-J. (2003). Chryseobacterium defluvii sp. nov., isolated from wastewater. Int J Syst Evol Microbiol 53, 93-97. 
Kim, K. K., Bae, H.-S., Schumann, P. \& Lee, S.-T. (2005a). Chryseobacterium daecheongense sp. nov., isolated from freshwater lake sediment. Int J Syst Evol Microbiol 55, 133-138.

Kim, K. K., Kim, M.-K., Lim, J. H., Park, H. Y. \& Lee, S.-T. (2005b). Transfer of Chryseobacterium meningosepticum and Chryseobacterium miricola to Elizabethkingia gen. nov. as Elizabethkingia meningoseptica comb. nov. and Elizabethkingia miricola comb. nov. Int J Syst Evol Microbiol 55, 1287-1293.

Li, Y., Kawamura, Y., Fujiwara, N., Naka, T., Liu, H., Huang, X., Kobayashi, K. \& Ezaki, T. (2003). Chryseobacterium miricola sp. nov., a novel species isolated from condensation water of space station Mir. Syst Appl Microbiol 26, 523-528.

MacFaddin, J. F. (1980). Biochemical Tests for Identification of Medical Bacteria, 2nd edn. Baltimore: Williams \& Wilkins.

Mai, T. \& Conner, D. (2001). Identification of bacteria found in broiler deboning operations. J Dairy Sci 84 (Suppl. 1), 297.

Mesbah, M., Premachandran, U. \& Whitman, W. B. (1989). Precise measurement of the $\mathrm{G}+\mathrm{C}$ content of deoxyribonucleic acid by highperformance liquid chromatography. Int J Syst Bacteriol 39, 159-167.

Nychas, G.-J. E. \& Drosinos, E. H. (1999). Meat and poultry spoilage. In Encyclopedia of Food Microbiology, pp. 1253-1259. Edited by R. K. Robinson, C. A. Batt \& P. D. Patel. San Diego: Academic Press.

Pitcher, D. G., Saunders, N. A. \& Owen, R. J. (1989). Rapid extraction of bacterial genomic DNA with guanidium thiocyanate. Lett Appl Microbiol 8, 151-156.

Pot, B., Vandamme, P. \& Kersters, K. (1994). Analysis of electrophoretic whole-organism protein fingerprints. In Chemical Methods in Prokaryotic Systematics, pp. 494-521. Edited by M. Goodfellow \& A. G. O'Donnell. Chichester: Wiley.

Shen, F.-T., Kämpfer, P., Young, C.-C., Lai, W.-A. \& Arun, A. B. (2005). Chryseobacterium taichungense sp. nov., isolated from contaminated soil. Int J Syst Evol Microbiol 55, 1301-1304.

Vandamme, P., Vancanneyt, M., Pot, B. \& 10 other authors (1992). Polyphasic taxonomic study of the emended genus Arcobacter with Arcobacter butzleri comb. nov. and Arcobacter skirrowii sp. nov., an aerotolerant bacterium isolated from veterinary specimens. Int J Syst Bacteriol 42, 344-356.

Vandamme, P., Bernardet, J.-F., Segers, P., Kersters, K. \& Holmes, B. (1994). New perspectives in the classification of the flavobacteria: description of Chryseobacterium gen. nov., Bergeyella gen. nov., and Empedobacter nom. rev. Int J Syst Bacteriol 44, 827-831.

Willems, A., Fernández-López, M., Muñoz-Adelantado, E., Goris, J., De Vos, P., Martínez-Romero, E., Toro, N. \& Gillis, M. (2003). Description of new Ensifer strains from nodules and proposal to transfer Ensifer adhaerens Casida 1982 to Sinorhizobium as Sinorhizobium adhaerens comb. nov. Request for an Opinion. Int J Syst Evol Microbiol 53, 1207-1217.

Yamaguchi, S. \& Yokoe, M. (2000). A novel protein-deamidating enzyme from Chryseobacterium proteolyticum sp. nov., a newly isolated bacterium from soil. Appl Environ Microbiol 66, 3337-3343.

Young, C.-C., Kämpfer, P., Shen, F.-T., Lai, W.-A. \& Arun, A. B. (2005). Chryseobacterium formosense sp. nov., isolated from the rhizosphere of Lactuca sativa L. (garden lettuce). Int J Syst Evol Microbiol 55, 423-426. 